\title{
Heavy Metal Risk Assessment in Bhavanapadu Creek Using Three Potamidid Snails - Telescopium telescopium, Cerithidea obtusa and Cerithidea cingulata
}

T Joseph Uday Ranjan* and K Ramesh Babu

Department of Marine Living Resources, College of Science and Technology, Andhra University, Visakhapatnam, Andhra Pradesh, India

\begin{abstract}
The study area experiences the sea water influx during high tide and fresh water during rainfall, flooding season etc. The Creek area is beset mostly with dwarf mangroves on either side, aquaculture ponds, agriculture fields, saltpans etc. The Creek life is influenced by these activities either directly or indirectly throughout the year. It is an almost unexplored area and is represented with diverse fauna and flora. In observation of that, the current investigation was undertaken to study the status of bioaccumulation of heavy metals, specifically $\mathrm{Cu}, \mathrm{Cd}, \mathrm{Zn}, \mathrm{Pb}, \mathrm{Ni}$ and $\mathrm{Fe}$ in soft tissues namely, in foot, digestive caecum, total body and operculum and shells of three different species of molluscs namely Telescopium telescopium, Cerithidea obtusa and Cerithidea cingulata using the Flame Atomic Absorption Spectrophotometer. All the outcomes were expressed in $\mu \mathrm{g} / \mathrm{gram}$ of dry weight and the end result reveals reflective amounts of heavy metals, except $\mathrm{Cd}, \mathrm{Pb}$ and $\mathrm{Ni}$. The statistical analysis of all in vitro studies of heavy metal concentration within and in between the matching organs of all tested species with oneway ANOVA showed significant difference except one. It can be concluded that, although molluscs provide information on the bioavailability of contaminants in ecosystems, it is hardly possible to derive any predictions of biological effects of these pollutants at the given level of exposure; such predictions are the main perspectives of biological effect monitoring.
\end{abstract}

Keywords: Bioaccumulation; Cerithidea cingulata; Cerithidea obtusa; Heavy metals; Telescopium telescopium

\section{Introduction}

Human activities can increase metal concentrations to higher than background levels. The mining and processing ores, domestic waste water effluents, storm water runoff and industrial wastes and discharges are certain main anthropogenic sources of heavy metal pollution [1]. Heavy metal pollution in aquatic ecosystem has been recognized as a serious environmental problem. In many cases, heavy metals occur in natural water bodies at levels below their toxic thresholds, however, due to their non degradable nature, such low concentrations may still pose risk of damage via uptake and subsequent bioaccumulation by organisms, which cannot be effectively metabolized and these absorbed metals are extracted. Several scientific observations have shown that heavy metals are bio concentrated or bioaccumulated in one or several compartments across food webs [2,3]. Besides, the contamination of resources with trace elements may have devastating effect on the natural ecosystem functioning, as well as cause a decrease of biodiversity and extinction of sensitive taxa [4]. Metal bioaccumulation can be of importance from the public health point of view, especially when humans consume the accumulators. Secondly, this phenomenon is now being exploited in the assessment of environmental quality, in addition to chemical surveys of water and sediment [5].

More and more attention has been drawn due to the wide occurrence of metal pollution in the aquatic system. Monitoring and prevention of heavy metal pollution is one of the hot topics in researches [6]. As shown in a review by Zhou et al. [6] many of the bioindicator papers were about metal pollution, wherein plants, invertebrates, fish and mammals were the dominant used bioindicator species. Each bioindicator shows the special merits for the biomonitoring of metal pollution in aquatic ecosystem when compared to the others.

Scrutinizing the literature on trial potamidid Snails, there is paucity of information on bioindicator studies with respect to heavy metal pollution of the Bhavanapadu creek study area. Hence the current investigation was undertaken to study the status of bioaccumulation of heavy metals, specifically $\mathrm{Cu}, \mathrm{Cd}, \mathrm{Zn}, \mathrm{Pb}, \mathrm{Ni}$ and $\mathrm{Fe}$ in soft tissues namely, in foot, digestive caecum, total body and operculum and shells of three different species of molluscs namely Telescopium telescopium, Cerithidea obtusa and Cerithidea cingulata.

\section{Materials and Methods}

\section{Chemicals}

Chemicals and reagents used for the study were purchased from Merck. All additional chemicals used were analytical grade. Altogether the experiments were performed at room temperature unless otherwise stated.

\section{Collection of test samples}

To avoid differences in metal content because of size or reproductive stage, only the commercial sized, forty individuals each for three different species of molluscs namely Telescopium telescopium, Cerithidea obtusa and Cerithidea cingulata were collected according to Saavedra et al. [7]. The gastropods were dissected and pooled into different tissues such as foot, digestive caecum, total body, operculum and shell. The shells and all different categories of tissues were dried at $60^{\circ} \mathrm{C}$ to constant dry weights. The dried tissue was reduced into fine powder in a pestle and mortar and was stored in dessicator for further analysis. The shell of individual species of molluscs was also finely ground. The resulting powder was collected, using a plastic sieve with $0.2 \mathrm{~mm}$ opening size and was stored in desiccator for further analysis.

\section{Flame atomic absorption spectrophotometer}

About $0.5 \mathrm{gm}$ of the test samples were digested in $10 \mathrm{ml}$ of concentrated nitric acid (AnalaR Grade; 69\%). They were placed in a

*Corresponding author: Joseph Uday Ranjan T, Department of Marine Living Resources, College of Science and Technology, Andhra University, Visakhapatnam-530 003, Andhra Pradesh, India, Tel: +9908034637; E-mail: ranjan.uday@gmail.com

Received June 21, 2016; Accepted July 11, 2016; Published July 19, 2016

Citation: Joseph TUR, Ramesh KB (2016) Heavy Metal Risk Assessment in Bhavanapadu Creek Using Three Potamidid Snails - Telescopium telescopium, Cerithidea obtusa and Cerithidea cingulata. J Environ Anal Toxicol 6: 385 doi:10.4172/2161-0525.1000385

Copyright: ( 2016 Joseph TUR, et al. This is an open-access article distributed under the terms of the Creative Commons Attribution License, which permits unrestricted use, distribution, and reproduction in any medium, provided the original author and source are credited. 
Citation: Joseph TUR, Ramesh KB (2016) Heavy Metal Risk Assessment in Bhavanapadu Creek Using Three Potamidid Snails - Telescopium telescopium, Cerithidea obtusa and Cerithidea cingulata. J Environ Anal Toxicol 6: 385. doi:10.4172/2161-0525.1000385

hot block digester first at low temperature $\left(40^{\circ} \mathrm{C}\right)$ for one hour and were then fully digested at high temperature $\left(140^{\circ} \mathrm{C}\right)$ for at least three hours. The digested samples were then diluted to a volume of $40 \mathrm{ml}$ with double distilled water. The sample was then filtered through Whatman No.1 filter paper (Dia: $110 \mathrm{~mm}$ ), then they were analysed for $\mathrm{Cu}, \mathrm{Cd}, \mathrm{Zn}, \mathrm{Pb}, \mathrm{Ni}$ and $\mathrm{Fe}$ by using an air-acetylene flame Atomic Absorption Spectrophotometer (AAS) Varian 220 Spectra AA. The samples were analyzed in three replicates. The data was presented in $\mu \mathrm{g} / \mathrm{g}$ of dry weight. Multi-level calibration standards were analyzed to generate calibration curves against which sample concentrations were calculated. Standard solutions were prepared from $1000 \mathrm{mg} / \mathrm{L}$ stock solutions of each metal (Merck Titrisol). All the glassware and plastic materials used were acid-washed in $10 \%$ concentrations of acid in order to minimize external contamination [8].

\section{Statistical analysis}

Oneway analysis of variance (ANOVA) was used to know the significance of heavy metal concentration within and in between the matching organs of all tested species. 'P' value less than 0.003 was considered as significant difference in the analysis. All the statistical analysis was resolved using SPSS software.

\section{Results and Discussion}

Metal bioavailability to organisms depends on various factors including geochemical and biological processes. Determination of metal concentration in an organism provides information on the bioavailable fraction of metal. However, measurement of metal in tissues does not provide information regarding the process controlling metal intake. Previously in Asia, investigations on the measurement, distribution and fate of heavy metals in the marine environment have been reported for a number of countries including Thailand, Malaysia, Japan, Korea and China [9-14]. Bhavanapadu Creek (Long: $18^{\circ} 33^{\prime}$ $52^{\prime \prime}$ to $18^{\circ} 32^{\prime} 11^{\prime \prime} \mathrm{N}$; Lat: $84^{\circ} 21^{\prime} 26^{\prime \prime} \mathrm{E}$ to $84^{\circ} 18^{\prime} 22^{\prime \prime} \mathrm{E}$ ) is located on the North East coast of Andhra Pradesh, adjoining the Bay of Bengal (Figure 1). The Bhavanapadu Creek mouth is an ecosystem harbouring rich and vulnerable species [15]. Luxuriant mangroves cover an approximately 2000 hectares of mangrove marshy land, mostly dominated by eight species of halophytes, two sea grasses [16] and nineteen molluscs [17]. The study area experiences the sea water influx during high tide and fresh water during rainfall, flooding season etc.
The Creek area is beset mostly with dwarf mangroves on either side, aquaculture ponds, agriculture fields, saltpans etc. The Creek life is influenced by these activities either directly or indirectly throughout the year. It is an almost unexplored area and is represented with diverse fauna and flora including the molluscs, among which the abundantly existing three Potamidid snails-Telescopium telescopium, Cerithidea obtusa and Cerithidea cingulata (Figure 2) were identified and selected for the cram.

It was observed that the magnitude of heavy metal accumulation in snails tissues depend upon type of heavy metal and the species of the snail. The observed differences in tissues metal concentrations between snail species might be due to variation in reproductive condition, genotype of the animal, difference in metabolic rate, body weight, trophic position, presence or absence of enzyme system that can degrade the pollutants [18]. Variability between closely related species was reflected by difference in the biokinetics of uptake, elimination and different physiological rates such as pumping, filtration and respiration. These qualities are specific for different species. Element concentrations in molluscs differ between different species due to species-specific ability/capacity to regulate or accumulate trace metals [19] and might be related to the species-specific digestive physiology and absorption rate of a metal across gut epithelium [20]. Differences in metal efflux rates are also important in determining interspecific differences in accumulated metal concentrations among the snail's species. Interaction of metals in body tissues seems to vary from species to species. At the same time the responses of the organism is specific for different element and substance [21]. Therefore, two species that live in a same place can differ in the types and concentrations of metals they accumulate [22]. The species which are more tolerant to respective metal accumulates more metal, while less tolerant species accumulate less metal or may not survive. It was also known that aquatic molluscs possess very diverse strategies in the handling and storage of accumulated metals [23].

The in progress exploration reveals that, in Cerithidea cingulata towering amount of copper was found in digestive caecum 143.0 \pm 4.1 and in foot $124.0 \pm 4.9$ and moderate amounts were found in total body and in operculum with $94.7 \pm 5.1$ and $59.1 \pm 4.0$. Very less amount $5.3 \pm 1.5$ was observed in shell. In Telescopium telescopium modest amounts of copper was found in operculum, foot, digestive
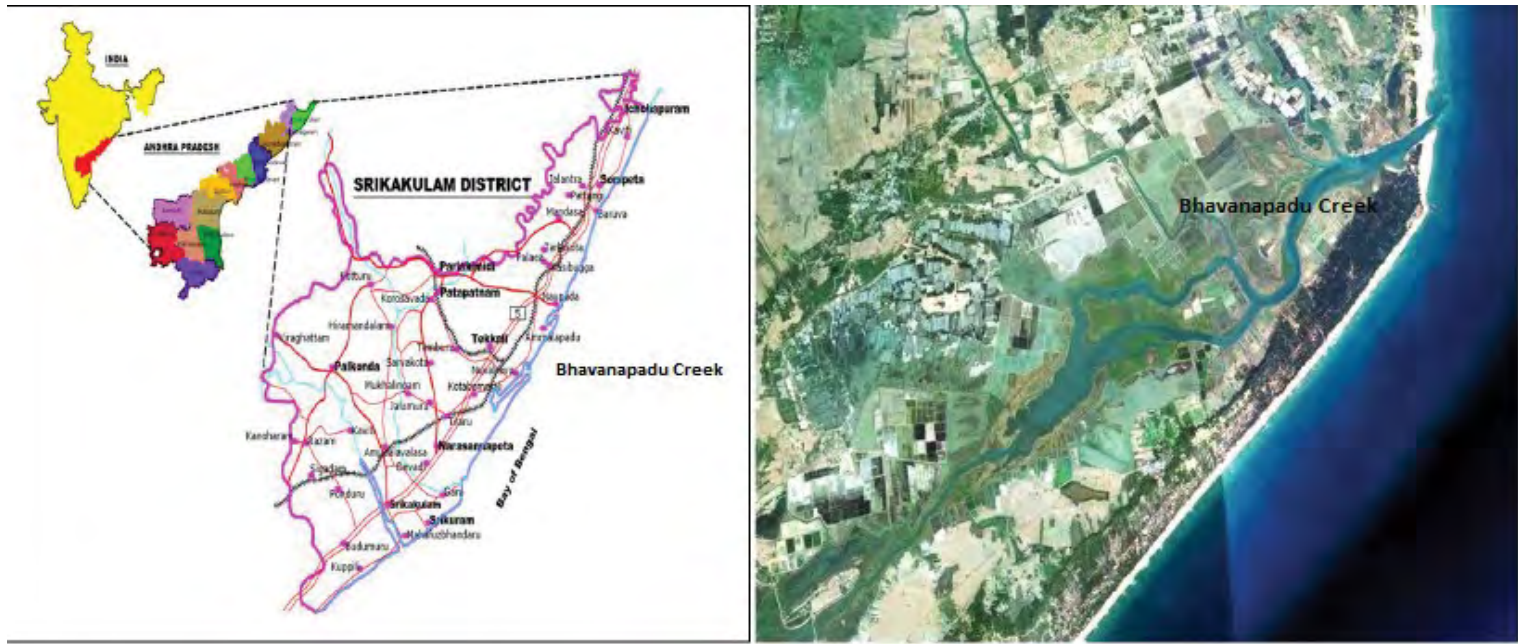

Figure 1: Study area and satellite map. 
Citation: Joseph TUR, Ramesh KB (2016) Heavy Metal Risk Assessment in Bhavanapadu Creek Using Three Potamidid Snails - Telescopium telescopium, Cerithidea obtusa and Cerithidea cingulata. J Environ Anal Toxicol 6: 385. doi:10.4172/2161-0525.1000385
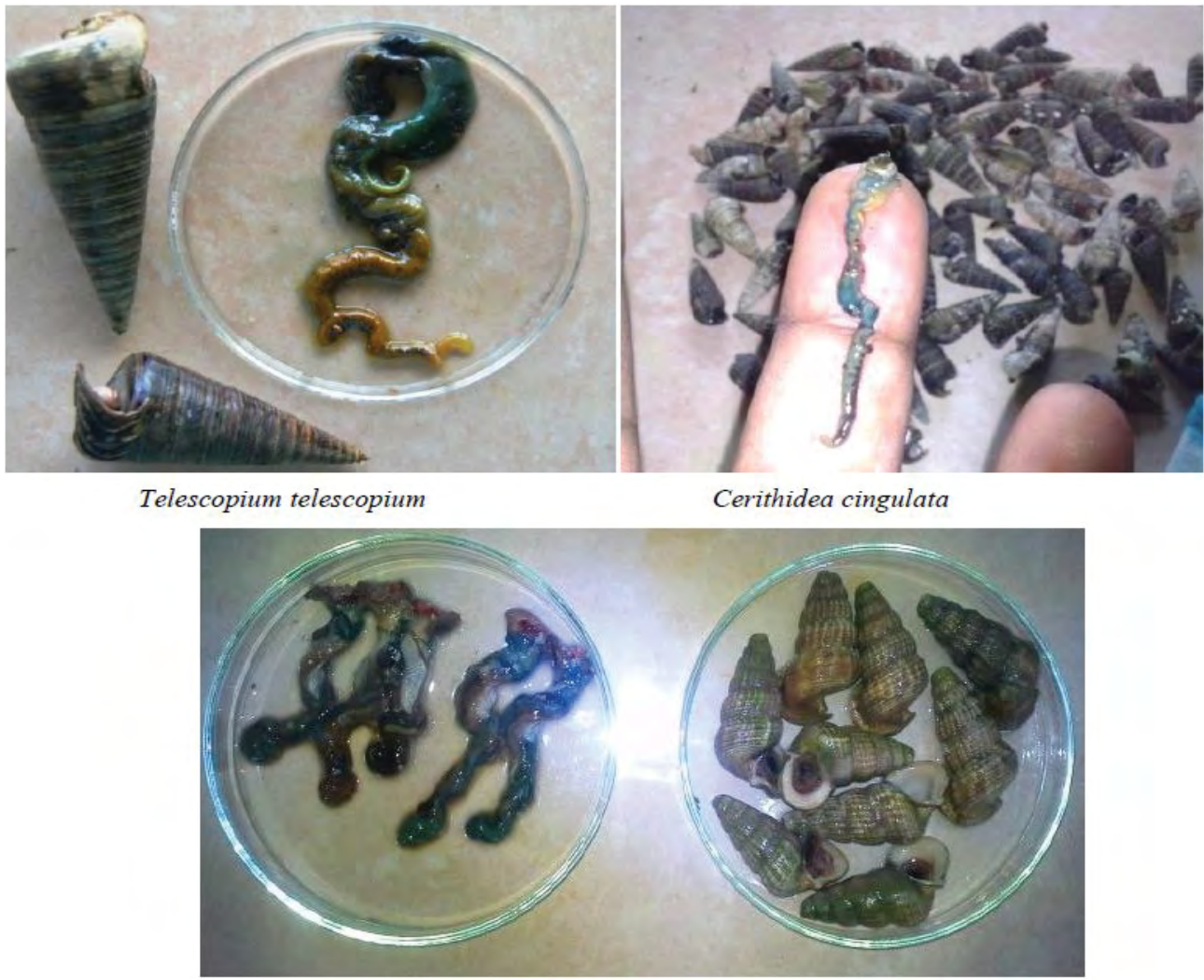

Cerithidea obtusa

Figure 2: Test molluscs.

caecum and total body; $50.7 \pm 1.9,95.1 \pm 4.8,88.2 \pm 4.2$ and $68.9 \pm 2.5$ respectively. Diminutive amount $9.9 \pm 0.95$ was experiential in shell. In Cerithidea obtusa high amount of copper was found in foot and total body with $116.2 \pm 7.2$ and $94.7 \pm 4.1$. Modest amount was found in digestive caecum and in operculum with $74.3 \pm 1.4$ and $42.3 \pm 2.7$ and less amount $3.47 \pm 0.43$ of copper was found in shell.

Elevated amount of cadmium was observed in shell of Telescopium telescopium with $3.12 \pm 0.96$ and $2.78 \pm 0.44,4.3 \pm 0.98$ and $1.79 \pm 0.45$ were observed in operculum, foot and in total body correspondingly. In Cerithidea cingulata high amount of cadmium was practical in operculum by means of $2.46 \pm 0.16$, where as in total body, foot and in shell were experienced with $1.43 \pm 0.07,1.22 \pm 0.21$ and $0.01 \pm 0.007$ in that order. Traces of cadmium was observed in Cerithidea obtusa, operculum, foot, shell and total body by means of $0.03 \pm 0.007,0.02$ $\pm 0.003 .0 .36 \pm 0.07$ and $0.001 \pm 0.0002$ respectively. Captivatingly no cadmium was observed in digestive systems of all three tested samples.

In Telescopium telescopium soaring amount of zinc was experimental in total body by $113.0 \pm 5.7$ and little amount was observed in shell by way of $5.91 \pm 1$ and restrained amount was observed in digestive caecum, foot and in operculum with $65.0 \pm 5.1,56.9 \pm 2.9$ and $43.9 \pm$ 4.0 in the same way. In Cerithidea cingulata elevated amount of zinc was observed in total body and in foot through $113.0 \pm 5.74$ and 93.0 \pm 3.4 respectively. Whereas, in digestive system and in operculum 77.5 \pm 6.5 and $38.9 \pm 3.3$ were noticed likewise. Traces of zinc specifically $3.33 \pm 0.3$ were pragmatic in shell. In Cerithidea obtusa high amount of zinc was observed in total body with $77.3 \pm 4.5$ and moderate amount in foot and digestive system with $49.1 \pm 4.6$ and $35.6 \pm 1.9$. Stumpy amount of zinc was observed in operculum and in shell by way of 14.3 \pm 2.8 and $6.36 \pm 0.84$ in that order.

Lofty amount of lead was observed in shell of Telescopium telescopium through $54.2 \pm 4.5$. Traces of lead were observed in operculum and in total body by $9.45 \pm 2.19$ and $10.0 \pm 2.8$. In Cerithidea cingulata, shell restrained high amount of lead $38.6 \pm 0.54$ and operculum with $16.3 \pm 2.9$, whereas stumpy amount was in total body with $0.94 \pm 0.28$. In Cerithidea obtusa, $0.89 \pm 0.13$ and $21.36 \pm 4.8$ of lead was observed in total body and in shell respectively. Foot and digestive caecum of $T$. telescopium, $C$. cingulata and along with the above, operculum of C. obtusa were not distinguished with lead.

In Telescopium telescopium gigantic and a reduced amount of nickel was observed in shells by means of $10.4 \pm 1.6$ and operculum with $0.22 \pm 0.09$, where as in total body $4.77 \pm 0.9$ of nickel was practical. In Cerithidea cingulata $2.89 \pm 0.29,0.34 \pm 0.12$ and 1.79 \pm 0.67 of nickel was observed in operculum, shell and in total body respectively. No nickel was observed in foot and digestive caecum of Telescopium telescopium and in Cerithidea cingulata. In Cerithidea obtusa, operculum and shell were identified with $0.24 \pm 0.1$ and $1.22 \pm$ 0.33 nickel correspondingly. Whereas in the foot, digestive caecum and total body nickel was not found.

In Telescopium telescopium, Cerithidea cingulata and in Cerithidea obtusa high amount of iron was noticed in total body with $1782.0 \pm 5.6$, $1543.0 \pm 4.5$ and $1458.0 \pm 8.2$ in that order. In Telescopium telescopium, operculum had $921.0 \pm 5.3$ and digestive caecum with $851.4 \pm 2.1$ of iron. Fewer amounts were observed in foot and shell $166.5 \pm 4.0$ and 248.2 
Citation: Joseph TUR, Ramesh KB (2016) Heavy Metal Risk Assessment in Bhavanapadu Creek Using Three Potamidid Snails - Telescopium telescopium, Cerithidea obtusa and Cerithidea cingulata. J Environ Anal Toxicol 6: 385. doi:10.4172/2161-0525.1000385

\pm 11.0 respectively. Operculum and digestive caecum of Cerithidea obtusa had $844.0 \pm 4.1$ and $406.0 \pm 7.3$ of iron. Diminutive amount $173.3 \pm 4.2$ was identified in shell. Iron content of Cerithidea cingulata operculum, digestive caecum, foot and shell was $638.0 \pm 12.5,406.0 \pm$ 3.9, $255.0 \pm 6.0$ and $189.5 \pm 5.9$ respectively. All the above mentioned results were expressed in $\mu \mathrm{g} / \mathrm{gram}$ of dry weight. The statistical analysis of all in vitro $(\mathrm{n}=3)$ studies of heavy metal concentration within and in between the matching organs of all tested species with oneway ANOVA showed significant difference except one. All the above fallouts were put on show in Table 1 and oneway ANOVA between heavy metals in different parts of three tested species were also displayed in addition (Tables 2-6)

In a number of previous investigations on the metal pollution of coastal sites and estuaries, various number of the indigenous biota have been engaged to evaluate the bioavailability levels of metals in the marine environment. It is known that molluscs accumulate organic and metallic pollutants at concentrations several orders of magnitude above those observed in the environment [24]. The accumulation of heavy metals has been reported in different molluscan species by different authors. Irato et al. [25] evaluated the accumulation of heavy metals in three species of bivalve molluscs M. galloprovincialis, Scapharca inaequivalvis and T. philippinarum. Shanmugam et al.
[26] estimated the bioaccumulation of some trace metals in a marine neogastropod Cymbium melo. Similarly from bivalves in P. viridis [27] and in 15 species of benthic invertebrates [28]. Kone et al. [29] studied the comparative survey of the levels of contamination of heavy metals in gastropod Tympanotonus fuscatus. Gabr and Gab-Alla [30] studied the effect of transplantation of heavy metals in two species namely Ruditapes decussates and Venerupis pullastra. Kesavan et al. [31] in Telescopium telescopium and Asha et al. [32] in Marcia opima and Donax cuneatus.

\section{Conclusion}

Snails have been successfully used as bioaccumulation indicators or monitors in the past and will also play a prominent role in this area of environmental surveillance in the future. It is noted that particular organ may be more effective tool than the whole soft tissue to monitor given metal in the mangrove mudflat. Nevertheless, it has to be considered that such studies can only offer rather limited insights into the ecological and ecotoxicological relevance of the actual pollutant exposure in the environment. Although they provide information on the bioavailability of contaminants in ecosystems, it is hardly possible to derive any predictions of biological effects of these pollutants at the given level of exposure; such predictions are the main perspectives of biological effect monitoring.

\begin{tabular}{|c|c|c|c|c|c|c|c|}
\hline \multirow{2}{*}{ Species } & \multirow{2}{*}{ Different organs } & Copper & Cadmium & Zinc & Lead & Nickel & Iron \\
\hline & & $(\mathrm{Cu})$ & $(\mathrm{Cd})$ & (Zn) & $(\mathrm{Pb})$ & (Ni) & $(\mathrm{Fe})$ \\
\hline \multirow{5}{*}{ T. telescopium } & Operculum & $50.7 \pm 1.9$ & $2.78 \pm 0.44$ & $43.9 \pm 4.0$ & $9.45 \pm 2.19$ & $0.22 \pm 0.09$ & $921.0 \pm 5.3$ \\
\hline & Foot & $95.1 \pm 4.8$ & $4.3 \pm 0.98$ & $56.9 \pm 2.9$ & - & - & $166.5 \pm 4.0$ \\
\hline & Digestive caecum & $88.2 \pm 4.2$ & - & $65.0 \pm 5.1$ & - & - & $851.4 \pm 2.1$ \\
\hline & Shell & $9.9 \pm 0.95$ & $3.12 \pm 0.96$ & $5.91 \pm 1.0$ & $54.2 \pm 4.5$ & $10.4 \pm 1.6$ & $248.2 \pm 11.0$ \\
\hline & Total body & $68.9 \pm 2.5$ & $1.79 \pm 0.45$ & $113.0 \pm 5.7$ & $10.0 \pm 2.8$ & $4.77 \pm 0.9$ & $1782.0 \pm 5.6$ \\
\hline \multirow{5}{*}{ C. obtusa } & Operculum & $42.3 \pm 2.7$ & $0.03 \pm 0.007$ & $14.3 \pm 2.8$ & - & $0.24 \pm 0.1$ & $844.0 \pm 4.1$ \\
\hline & Foot & $116.2 \pm 7.2$ & $0.02 \pm 0.003$ & $49.1 \pm 4.6$ & - & - & $252.3 \pm 10.4$ \\
\hline & Digestive caecum & $74.3 \pm 1.4$ & - & $35.6 \pm 1.9$ & - & - & $406.0 \pm 7.3$ \\
\hline & Shell & $3.47 \pm 0.43$ & $0.36 \pm 0.07$ & $6.36 \pm 0.84$ & $21.36 \pm 4.8$ & $1.22 \pm 0.33$ & $173.3 \pm 4.2$ \\
\hline & Total body & $94.7 \pm 4.1$ & $0.001 \pm 0.0002$ & $77.3 \pm 4.5$ & $0.89 \pm 0.13$ & - & $1458.0 \pm 8.2$ \\
\hline \multirow{5}{*}{ C. cingulata } & Operculum & $59.1 \pm 4.0$ & $2.46 \pm 0.16$ & $38.9 \pm 3.3$ & $16.3 \pm 2.9$ & $2.89 \pm 0.29$ & $638.0 \pm 12.5$ \\
\hline & Foot & $124.0 \pm 4.9$ & $1.22 \pm 0.21$ & $93.0 \pm 3.4$ & - & - & $255.0 \pm 6.0$ \\
\hline & Digestive caecum & $143.0 \pm 4.1$ & - & $77.5 \pm 6.5$ & - & - & $406.0 \pm 3.9$ \\
\hline & Shell & $5.3 \pm 1.5$ & $0.01 \pm 0.007$ & $3.33 \pm 0.3$ & $38.6 \pm 0.54$ & $0.34 \pm 0.12$ & $189.5 \pm 5.9$ \\
\hline & Total body & $94.7 \pm 5.1$ & $1.43 \pm 0.07$ & $113.0 \pm 5.74$ & $0.94 \pm 0.28$ & $1.79 \pm 0.67$ & $1543.0 \pm 4.5$ \\
\hline
\end{tabular}

Each value represents the mean \pm SD of three replicates

Table 1: Heavy metal concentrations ( $\mu \mathrm{g} / \mathrm{gram}$ of dry weight) in unlike soft tissues and shells of tested species. 
Citation: Joseph TUR, Ramesh KB (2016) Heavy Metal Risk Assessment in Bhavanapadu Creek Using Three Potamidid Snails - Telescopium telescopium, Cerithidea obtusa and Cerithidea cingulata. J Environ Anal Toxicol 6: 385. doi:10.4172/2161-0525.1000385

Page 5 of 7

\begin{tabular}{|c|c|c|c|c|c|c|}
\hline & Operculum & Sum of Squares & df & Mean Square & $\mathbf{F}$ & Sig. \\
\hline \multirow[t]{3}{*}{$\mathrm{Cu}$} & Between Groups & 423.36 & 2 & 211.68 & 22.909 & 0.002 \\
\hline & Within Groups & 55.44 & 6 & 9.24 & & \\
\hline & Total & 478.8 & 8 & & & \\
\hline \multirow[t]{3}{*}{$\mathrm{Cd}$} & Between Groups & 13.57 & 2 & 6.785 & 89.452 & 0 \\
\hline & Within Groups & 0.455 & 6 & 0.076 & & \\
\hline & Total & 14.025 & 8 & & & \\
\hline \multirow[t]{3}{*}{$\mathrm{Zn}$} & Between Groups & 1506.32 & 2 & 753.16 & 65.115 & 0 \\
\hline & Within Groups & 69.4 & 6 & 11.567 & & \\
\hline & Total & 1575.72 & 8 & & & \\
\hline \multirow[t]{3}{*}{$\mathrm{Pb}$} & Between Groups & 403.461 & 2 & 201.73 & 46.225 & 0 \\
\hline & Within Groups & 26.184 & 6 & 4.364 & & \\
\hline & Total & 429.645 & 8 & & & \\
\hline \multirow[t]{3}{*}{$\mathrm{Ni}$} & Between Groups & 14.106 & 2 & 7.053 & 201.677 & 0 \\
\hline & Within Groups & 0.21 & 6 & 0.035 & & \\
\hline & Total & 14.315 & 8 & & & \\
\hline \multirow[t]{3}{*}{$\mathrm{Fe}$} & Between Groups & 128454 & 2 & 64227 & 958.85 & 0 \\
\hline & Within Groups & 401.9 & 6 & 66.983 & & \\
\hline & Total & 128855.9 & 8 & & & \\
\hline
\end{tabular}

$\mathrm{P}<0.003$ was considered as significant difference

Table 2: Heavy metal concentration in operculum of three tested species through ANOVA.

\begin{tabular}{|c|c|c|c|c|c|c|}
\hline & Foot & Sum of Squares & df & Mean Square & $\mathbf{F}$ & Sig. \\
\hline \multirow{3}{*}{$\mathrm{Cu}$} & Between Groups & 1339.193 & 2 & 669.597 & 20.001 & 0.002 \\
\hline & Within Groups & 200.865 & 6 & 33.478 & & \\
\hline & Total & 1540.059 & 8 & & & \\
\hline \multirow{3}{*}{ Cd } & Between Groups & 29.245 & 2 & 14.622 & 43.257 & 0 \\
\hline & Within Groups & 2.028 & 6 & 0.338 & & \\
\hline & Total & 31.273 & 8 & & & \\
\hline \multirow{3}{*}{$\mathrm{Zn}$} & Between Groups & 3288.999 & 2 & 1644.5 & 120.588 & 0 \\
\hline & Within Groups & 81.824 & 6 & 13.637 & & \\
\hline & Total & 3370.823 & 8 & & & \\
\hline \multirow{3}{*}{$\mathrm{Pb}$} & Between Groups & 0 & 2 & 0 & . & . \\
\hline & Within Groups & 0 & 6 & 0 & & \\
\hline & Total & 0 & 8 & & & \\
\hline \multirow{3}{*}{$\mathrm{Ni}$} & Between Groups & 0 & 2 & 0 & . & . \\
\hline & Within Groups & 0 & 6 & 0 & & \\
\hline & Total & 0 & 8 & & & \\
\hline \multirow{3}{*}{$\mathrm{Fe}$} & Between Groups & 15218.347 & 2 & 7609.173 & 142.284 & 0 \\
\hline & Within Groups & 320.873 & 6 & 53.479 & & \\
\hline & Total & 15539.22 & 8 & & & \\
\hline
\end{tabular}

$\mathrm{P}<0.003$ was considered as significant difference.

Table 3: Heavy metal concentration in foot of three tested species through ANOVA.

\begin{tabular}{|c|c|c|c|c|c|c|}
\hline & Digestive caecum & Sum of Squares & df & Mean Square & $\mathbf{F}$ & Sig. \\
\hline \multirow{3}{*}{$\mathrm{Cu}$} & Between Groups & 7915.94 & 2 & 3957.97 & 322.31 & 0 \\
\hline & Within Groups & 73.68 & 6 & 12.28 & & \\
\hline & Total & 7989.62 & 8 & & & \\
\hline \multirow{3}{*}{$\mathrm{Cd}$} & Between Groups & 0 & 2 & 0 & . & . \\
\hline & Within Groups & 0 & 6 & 0 & & \\
\hline & Total & 0 & 8 & & & \\
\hline \multirow{3}{*}{$\mathrm{Zn}$} & Between Groups & 2776.22 & 2 & 1388.11 & 57.147 & 0 \\
\hline & Within Groups & 145.74 & 6 & 24.29 & & \\
\hline & Total & 2921.96 & 8 & & & \\
\hline \multirow{3}{*}{$\mathrm{Pb}$} & Between Groups & 0 & 2 & 0 & . & . \\
\hline & Within Groups & 0 & 6 & 0 & & \\
\hline & Total & 0 & 8 & & & \\
\hline \multirow{3}{*}{$\mathrm{Ni}$} & Between Groups & 0 & 2 & 0 & . & . \\
\hline & Within Groups & 0 & 6 & 0 & & \\
\hline & Total & 0 & 8 & & & \\
\hline
\end{tabular}


Citation: Joseph TUR, Ramesh KB (2016) Heavy Metal Risk Assessment in Bhavanapadu Creek Using Three Potamidid Snails - Telescopium telescopium, Cerithidea obtusa and Cerithidea cingulata. J Environ Anal Toxicol 6: 385. doi:10.4172/2161-0525.1000385

Page 6 of 7

\begin{tabular}{|c|c|c|c|c|c|}
\hline \multirow{3}{*}{$\mathrm{Fe}$} & Between Groups & 396821.71 & 2 & 198410.85 & $8.08 \mathrm{E}+03$ \\
\cline { 2 - 5 } & Within Groups & 147.287 & 6 & 24.548 \\
\cline { 2 - 6 } & Total & 396969 & 8 & \\
\hline
\end{tabular}

$\mathrm{P}<0.003$ was considered as significant difference.

Table 4: Heavy metal concentration in digestive caecum of three tested species through ANOVA.

\begin{tabular}{|c|c|c|c|c|c|c|}
\hline & Shell & Sum of Squares & df & Mean Square & $\mathbf{F}$ & Sig. \\
\hline \multirow{3}{*}{$\mathrm{Cu}$} & Between Groups & 65.671 & 2 & 32.836 & 29.364 & 0.001 \\
\hline & Within Groups & 6.709 & 6 & 1.118 & & \\
\hline & Total & 72.381 & 8 & & & \\
\hline \multirow{3}{*}{$\mathrm{Cd}$} & Between Groups & 17.412 & 2 & 8.706 & 27.825 & 0.001 \\
\hline & Within Groups & 1.877 & 6 & 0.313 & & \\
\hline & Total & 19.29 & 8 & & & \\
\hline \multirow{3}{*}{$\mathrm{Zn}$} & Between Groups & 16.04 & 2 & 8.02 & 13.208 & $.006^{*}$ \\
\hline & Within Groups & 3.643 & 6 & 0.607 & & \\
\hline & Total & 19.683 & 8 & & & \\
\hline \multirow{3}{*}{$\mathrm{Pb}$} & Between Groups & 1619.121 & 2 & 809.56 & 56.546 & 0 \\
\hline & Within Groups & 85.901 & 6 & 14.317 & & \\
\hline & Total & 1705.021 & 8 & & & \\
\hline \multirow{3}{*}{$\mathrm{Ni}$} & Between Groups & 187.608 & 2 & 93.804 & 99.335 & 0 \\
\hline & Within Groups & 5.666 & 6 & 0.944 & & \\
\hline & Total & 193.274 & 8 & & & \\
\hline \multirow{3}{*}{$\mathrm{Fe}$} & Between Groups & 9321.583 & 2 & 4660.791 & 80.466 & 0 \\
\hline & Within Groups & 347.533 & 6 & 57.922 & & \\
\hline & Total & 9669.116 & 8 & & & \\
\hline
\end{tabular}

*denotes insignificance; $\mathrm{P}<0.003$ was considered as significant difference.

Table 5: Heavy metal concentration in shells of three tested species through ANOVA.

\begin{tabular}{|c|c|c|c|c|c|c|}
\hline & Total body & Sum of Squares & df & Mean Square & $\mathbf{F}$ & Sig. \\
\hline \multirow{3}{*}{$\mathrm{Cu}$} & Between Groups & 1331.28 & 2 & 665.64 & 40.828 & 0 \\
\hline & Within Groups & 97.82 & 6 & 16.303 & & \\
\hline & Total & 1429.1 & 8 & & & \\
\hline \multirow{3}{*}{$\mathrm{Cd}$} & Between Groups & 5.372 & 2 & 2.686 & 38.354 & 0 \\
\hline & Within Groups & 0.42 & 6 & 0.07 & & \\
\hline & Total & 5.792 & 8 & & & \\
\hline \multirow{3}{*}{$\mathrm{Zn}$} & Between Groups & 2548.98 & 2 & 1274.49 & 44.589 & 0 \\
\hline & Within Groups & 171.5 & 6 & 28.583 & & \\
\hline & Total & 2720.48 & 8 & & & \\
\hline \multirow{3}{*}{$\mathrm{Pb}$} & Between Groups & 165.078 & 2 & 82.539 & 30.172 & 0.001 \\
\hline & Within Groups & 16.414 & 6 & 2.736 & & \\
\hline & Total & 181.492 & 8 & & & \\
\hline \multirow{3}{*}{$\mathrm{Ni}$} & Between Groups & 34.898 & 2 & 17.449 & 38.41 & 0 \\
\hline & Within Groups & 2.726 & 6 & 0.454 & & \\
\hline & Total & 37.624 & 8 & & & \\
\hline \multirow{3}{*}{$\mathrm{Fe}$} & Between Groups & 169311.74 & 2 & 84655.868 & $2.15 E+03$ & 0 \\
\hline & Within Groups & 236.607 & 6 & 39.434 & & \\
\hline & Total & 169548.34 & 8 & & & \\
\hline
\end{tabular}

$\mathrm{P}<0.003$ was considered as significant difference.

Table 6: Heavy metal concentration in total body of three tested species through ANOVA.

\section{Acknowledgements}

The authors are grateful to the Head, Department of Marine Living Resources, Andhra University for the facilities.

\section{References}

1. Csuros M, Csuros C (2002) Environmental sampling and analysis for metals. Lewis Publishers, CRC Press Company.

2. Soegianto A, Irawan B (2009) Bioaccumulation of heavy metals in aquatic animals collected from coastal waters of Gecko Indonesia. Journal of Water Environment Pollutant 2: 95-100.

3. Celechovska O, Malota L, Zima S (2008) Entry of heavy metals into food chains: A 20-year comparison study in northern Moravia (Czech Republic) Acta Veterinaria Brno 77: 645-652.

4. Bonanno G, Lo Giudice RL (2010) Heavy metal bioaccumulation by the organs of Phragmites australis (common reed) and their potential use as contamination indicators. Ecological Indicators 10: 639-645.

5. Javanshir A, Shapoori M, Moëzzi F (2011) Influence of Water hardness (Calcium concentration) on the absorption of Cadmium by the mangrove oyster Crassostrea gasar (Ostreidae; Bivalvia). Journal of Food Agriculture and Environment 9: 724-727

6. Zhou Q, Zhang J, Fu J, Shi J, Jiang G (2008) Biomonitoring: an appealing tool for assessment of metal pollution in the aquatic ecosystem. Anal Chim Acta 606: $135-150$ 
Citation: Joseph TUR, Ramesh KB (2016) Heavy Metal Risk Assessment in Bhavanapadu Creek Using Three Potamidid Snails - Telescopium telescopium, Cerithidea obtusa and Cerithidea cingulata. J Environ Anal Toxicol 6: 385. doi:10.4172/2161-0525.1000385

7. Saavedra Y, Gonzalez A, Fernandez P, Blanco J (2004) Interspecific variation of metal concentrations in three bivalve molluscs from Galicia. Archives of Environmental Contamination and Toxicology 47: 341-351.

8. Yap CK, Ismail A, Tan SG (2003) Can the byssus of green-lipped mussel Perna viridis (Linnaeus) from the west coast of Peninsular Malaysia be a biomonitoring organ for $\mathrm{Cd}, \mathrm{Pb}$ and $\mathrm{Zn}$ ? Field and laboratory studies. Environ Int 29: 521-528.

9. Menasveta P, Cheevaparanapiwat V (1981) Heavy metals, organochlorine pesticides and PCBs in green mussels, mullets and sediments of river mouths in Thailand. Marine Pollution Bulletin 12: 19-25.

10. Seng C, Lim P, Ang T (1987) Heavy metal concentrations in coastal seawater and sediments off Prai Industrial Estate, Penang, Malaysia. Marine Pollution Bulletin 18: 611-612.

11. Fukushima K, Saino T, Kodama $Y$ (1992) Trace metal contamination in Tokyo Bay, Japan. The Science of the Total Environment 125: 373-389.

12. Lee KW, Kang HS, Lee SH (1998) Trace elements in the Korean coasta environment. Sci Total Environ 214: 11-19.

13. Hong H, Lin J (1989) Preliminary study on the distribution of nutrients, organic matter, trace metals in sea surface microlayer in Xiamen Bay and Jiulong Estuary. Acta Oceanologica Sinica 9: 81-90.

14. Yuan CG, Shi JB, He B, Liu JF, Liang LN, et al. (2004) Speciation of heavy metals in marine sediments from the East China Sea by ICP-MS with sequential extraction. Environ Int 30: 769-783.

15. Wetlands of Srikakulam District (2012) An Ecological Status Survey-Final Report. Salim Ali Centre for Ornithology and Natural History (SACON).

16. Swain PK, Rama Rao N, Sanjai M (2008) New Mangrove Habitats and Additions to the Flora of Srikakulam District, Andhra Pradesh, India. Indian Journal of Forestry 31: 431-434.

17. Ranjan Uday JT, Babu RK (2014) Molluscan Diversity of Bhavanapadu Mangroves, Northeast Coast of Andhra Pradesh, India. Bulletin of Environment, Pharmacology and Life Sciences 4: 73-79.

18. Valavanidis A, Vlachogianni T (2010) Integrated Biomarkers in Aquatic Organisms as a Tool for Biomonitoring Environmental Pollution and Improved Ecological Risk Assessment. Science advances on environment, toxicology \& ecotoxicology issues, pp: 1-12.

19. Christopher BN, dome Ekaluo UB, Asuquo FE (2010) Comparative bioaccumulation of heavy metals ( $\mathrm{Fe}, \mathrm{Mn}, \mathrm{Zn}, \mathrm{Cu}, \mathrm{Cd}$, and $\mathrm{Cr}$ ) by some edible aquatic molluscs from the Atlantic coastline of South Eastern Nigeria. World Journal of Fish and Marine Sciences 2: 317-321.

20. Lee JS, Lee BG (2005) Effects of salinity, temperature and food type on the uptake and elimination rates of $\mathrm{Cd}, \mathrm{Cr}$ and $\mathrm{Zn}$ in the Asiatic Clam Corbicula fluminea. Ocean Science Journal 40: 79-89.
21. Waykar B Deshmukh G (2012) Evaluation of bivalves as bioindicators of metal pollution in freshwater. Bull Environ Contam Toxicol 88: 48-53.

22. Wang WX (2002) Interactions of trace metals and different marine food chains Marine Ecology Progress Series 243: 295-309.

23. Rainbow PS (2002) Kenneth Mellanby Review Award. Trace metal concentrations in aquatic invertebrates: why and so what? Environ Pollut 120: 497-507.

24. Bryan GW, Langston WJ, Hummerstone LG, Burt GR, Ho YB (1983) An assessment of the gastropod, Littorina littorea, as an indicator of heavy-metal contamination in United Kingdom estuaries. Journal of the Marine Biological Association (UK) 63: 327-345.

25. Irato P, Santovita G, Carsini A, Piccinni E, Albergoni V (2003) Meta accumulation and binding protein induction in Mytilus gallprovincialis, Scapharca inaequivalvis and Tapes philippinarum from the lagoon of Venice. Archives of Environmental Contamination and Toxicology 44: 476-484.

26. Annian S, Palpandi C, Sambasivam S (2007) Some valuable fatty acids exposed from wedge clam Donax cuneatus (Linnaeus). African Journal of Biochemistry Research 1: 014-018.

27. Yap CK, Ismail A, Tan SG, Rahim Ismail A (2007) The distribution of the heavy metals $(\mathrm{Cu}, \mathrm{Pb}$ and $\mathrm{Zn})$ in the soft and hard tissues of the green-lipped musse Perna viridis (Linnaeus) collected from Pasir Panjang, Peninsular Malaysia. Pertanika Journal of Tropical Agricultural Science 30: 1-10.

28. Huang $\mathrm{H}, \mathrm{Wu}$ JY, Wu JH (2007) Heavy metal monitoring using bivalved shellfish from Zhejiang coastal waters, East China Sea. Environ Monit Assess 129: 315-320.

29. Kone M, Dramane D, Karim Sory T, Ardjoana D, Pascal Valentin H (2008) Comparison of trace element contamination level $(\mathrm{Cu}, \mathrm{Zn}, \mathrm{Fe}, \mathrm{Cd}$ and $\mathrm{Pb})$ in the soft tissues of the Gastropods Tympanotonus fuscatus radula collected in Ebrie Lagoon, evidence of the risk linked to lead and cadmium. African Journal of Biotechnology 7: 811-820.

30. Gabr HR, Gab-Alla A (2008) Effect of transplantation on heavy meta concentrations in commercial clams of lake Timsah, Suez canal; Egypt Oceanologia 50: 83-93.

31. Kesavan K, Raja P, Ravi V, Rajagopal S (2010) Heavy metals in Telescopium telescopium and sediments from two stations of Vellar Estuary, Southeast Coast of India. Thalassas. An International Journal of marine Sciences 26: 33-39.

32. Asha PS, Krishnakumar PK, Kaladharan P, Prema D, Diwakar K, et al. (2010) Heavy metal concentration in seawater, sediment and bivalves off Tuticorin The Marine Biological Association of India 52: 48-54. 